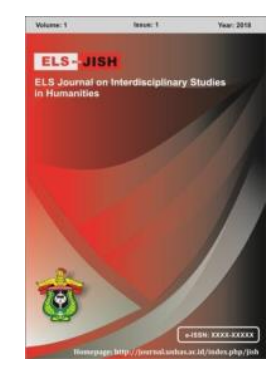

ELS-JISH

ELS Journal on Interdisciplinary Studies on Humanities

Volume 3 Issue 1, 2020

ISSN (print) : 2621-0843

ISSN (online) : 2621-0835

Homepage : http://journal.unhas.ac.id/index.php/jish

\title{
The Impact of Face Threatening Acts on Hearer (The Wife) Face in A Household Conflict: A Pragmatic Study
}

\author{
Sutiadi Rahmansyah', Tajudin Nur ${ }^{2}$, Davidescu Cristiana Victoria Marta ${ }^{3}$, \\ Lia Maulia Indrayani ${ }^{4}$ \\ 1 traveler14@gmail.com
}

\begin{abstract}
Conflict is a problem that is often faced in daily life, including husband and wife. Conflict in the household can lead to positive and negative things such as a divorce or violences in a household. The problem of conflict is closely related to the threat of "face" or a person selfesteem. The purpose of this article is to study the impact of face experienced by hearer (wife) in a household conflict that is particularly occurred on wife after her husband performs Face Threatening Acts. The method used in this research was qualitative, descriptive methods, i.e. it gives descriptive result about the impact of Face Threatening Acts usage and strategies in a household conflict obtained from several popular psychology books. The results showed that in general the impact of FTA used by a husband against his wife in the household conflict caused face loss on behalf of his wife (the loss of self-esteem). This happened because her feelings were more dominant and she generally avoided a conflict that could trigger further disputes with her husband to maintain her household.
\end{abstract}

Keywords: conflict, face, qualitative, face loss, pragmatics.

How to cite: Rahmansyah, S., et. al. (2020). The Impact of Face Threatening Acts on Hearer (The Wife) Face in A Household Conflict: A Pragmatic Study. ELS Journal on Interdisciplinary Studies in Humanities, 3(1), 140-149. DOI: http://dx.doi.org/10.34050/els-jish.v3i1.9427

\section{Introduction}

Conflict is a problem that often occurs in everyday life. Research on conflict has been much a concern on research such as: conflict in Justice (Penman, 1990), conflict in the family (Vuchinich, 1990), conflict in army training (Culpeper, 1996), conflict in several countries (Labov, 1972; Goodwin \& Goodwin, 1990), conflicts between doctors and patients (Mehan, 1990), conflict in therapy (Labov \& Fanshel, 1977), conflict in everyday conversation (Beebe, 1995) as well as in fictional characters (Tannen, 1990; Culpeper, 1998). Conflict in a household is something that is quite common for husbands and wife and it can lead to either positive or negative impacts for couples who are involved.

This conflict can arise as a result of speech. According to Honda (2012), conflict is defined as an activity of utterance when two parties try to maintain their two positions in terms of opposition, or a negative manifestation towards

${ }^{1,2,3,4}$ Universitas Padjadjaran, Indonesia 
the other party's position that contradicts with personal viewpoints. Utterance is quite significant in triggering conflict in a household. This happens because utterance closely relates to the realization of one's thoughts. Through words or utterance, people can feel that they have been harassed, threatened, blasphemed, ridiculed, and etc. Furthermore, if that kind of action is responded by each of the participant then it can lead them to a conflict. To examine matters relates to conflicts that arise as a result of utterances. It cannot be separated from pragmatic study, especially "face" and "Face Threatening Acts (FTA)".

There are many Face Threatening Act (FTA) studies that have been done by researchers however many of these studies have not been in detail discussing the issue of household conflicts. Studies on FTA that lead to conflict issues were carried out by Georgakopoulou (2001) who discussed expressions of disapproval in adolescent conversations in Greece; Laforest (2002) who examined the disclosure of complaints in family conversations in Montreal; Haugh (2010) who examined about "Jockular Mockery" or disclosure of ridicule in everyday conversation in English. Another specific research that relates to conflict carried out by Lee (2008). Lee (2008) discussed strategies in overcoming accusations in the conflict of married couples based on four television shows in South Korea by using symbolic actions. Although Lee's research (2008) related to conflict, his research did not use pragmatic approaches but sociolinguistic approaches.

The meaning of "face" as expressed by Brown and Levinson (1987) is very closely related to the "self-esteem" that is owned by everyone. In general, this notion of face is owned by everyone. According to Brown and Levinson (1987), every adult participant has a desire that his/her self-esteem or "face" is free and is not interfered or impeded by others. In other words, everyone has a desire that his/her dignity can be respected, liked, and understood by others. This is the main topic related to "face." So clearly, if someone does not want to experience a conflict with others, then that person must be able to maintain both of his/her and other faces. However, in everyday life, threats to "face" are unavoidable or it is known as Face Threatening Acts (FTA) (Brown and Levinson, 1987).

Humans have desires, talents and behaviors to connect and interact with other people who then give rise to special processes for doing things and seeing things (Rahman, 2019), as well as, a desire that their self-esteem is not interfered or want their "face" to be respected. When someone feels his/her face is threatened, there are two options that can be chosen by the person: First, the person will maintain his/her face by counter-attacking the threat. Second, the person can choose not to take it seriously by giving up his/her face (having face loss). The impact of this action depends on the participant itself along with the selection of the Face Threatening Act strategies used by him/her when performing the act. The impact of the selection of this strategy also determines whether or not the conflict will continue between participants.

In a household, a wife is closely related to her obligations as someone who serves her husband in all his needs, provides food for her husband, and obeys her husband's orders. Therefore, in a household conflict the wife will also 
try to avoid conflicts with her husband in order to respect her husband even though she has to give up his face (lose face). This article will analyze the impact of FTA on hearer's face (wife) after the selection of FTA strategies in a household conflict. The data were based on dialogues taken from several popular psychology books.

\section{Method}

The method used in this research was descriptive qualitative method. A descriptive qualitative method according to Bogdan and Taylor cited in Moeleong (1993) is a research procedure that produces descriptive data in the form of words both in verbal and writing. Djajasudarma (1993) states that the purpose of the descriptive method is to make a systematic, factual and accurate picture about the phenomena that are being researched. Nawawi (1983) explains that descriptive approach is defined as a problem-solving procedure that is investigated by describing the state of the subject or the object of research at the present time based on actual situations.

A descriptive qualitative approach was carried out on dialogues containing household conflicts found in popular psychology books. This was done by describing types, strategies and responses of Face Threatening Acts used by participant utterances involved in a household conflict. The aim of using this method is to clarify and give an idea of Face Threatening Act usage in a household conflict and reveals the impact of Face Threatening Act usage to the hearer face in a household conflict.

\subsection{Data}

The data for this research were transcriptions as samples of case studies happened in psychology counseling's. These transcriptions were written down in forms of dialogues and used in psychology books. Based on the statements of the authors of the books listed in the books, the names of the participants listed in the books are deliberately changed or disguised to maintain participant privacy but the illustration of events and their integrity can be guaranteed.

The title of psychology books used in this research are: 1) Wired for love: How understanding your partner's brain and attachment style can help you defuse conflict and build a secure relationship by Tatkin, S. This book was published in 2011 by New Harbinger Publications, Oakland, California. 2) Couple skills: Making your relationship work by McKay, M., Fanning, P., \& Paleg, K. published in 1994 by New Harbinger Publications, Oakland, California 3) Crucial conversations: Tools for talking when stakes are high. By Patterson. $\mathrm{K}$ published in 2002 by McGraw-Hill, New York.

The author considered that the use of household conflict transcripts in the form of dialogues in psychology books was relevant to be used as data. This happens because these transcriptions represent the actual event of a conflict if it is compared to data obtained from television shows, films, or novels that tend to be imaginative. In addition, it is very difficult to get data on household conflicts that are obtained directly from the field using the recording and tapping techniques because conflicts are usually personal, and their presence cannot be predicted. 


\subsection{Data Analysis Procedures}

This study used two procedures to analyze data. The first procedure was carried out with the following steps: 1) Selecting data to identify the presence or absence of Face Threatening Acts data by observing the samples of dialogues in popular psychology books 2) Note-taking and selecting relevant data in accordance with the research topic. The second procedure that the authors undertook after the data was obtained was as follows: 1) Describing and analyzing types of Face Threatening Acts in household conflicts 2) Describing and analyzing Face Threatening Acts strategies that can trigger conflicts in the household 3) Describing and analyzing the impact to the hearer (wife) face as a response to the Face Threatening Act usage.

\section{Findings}

Based on the data gained and filtered through the research method, from total 30 (thirty) dialogues about conflict found in three popular psychological books, 2 (two) of them are the strongest findings for FTA impact to the hearer (wife) as samples to be discussed in this paper. The impacts for hearer (wife) may vary, but in general based on the data the wife mostly had face loss after the FTA did by her husband. This face loss still happens even though the wife had already tried to avoid it by counter attacking her husband. Further samples are explained below:

\subsection{Hearer (Wife) Losing Face after Counter Attacking Speaker (Husband)}

The hearer (wife) do counter attacking FTA however after she does that she still gives up her face to her husband (loss face) to avoid further conflict. For example, this action can be seen in the following dialogues:

\begin{tabular}{|c|c|}
\hline $\begin{array}{l}\text { Physical context } \\
\text { Epistemic } \\
\text { context }\end{array}$ & $\begin{array}{l}\text { Inside the house. } \\
\text { Franklin and Leia are a married couple. Leia } \\
\text { tried to invite her husband to visit his mother, } \\
\text { which caused conflict. }\end{array}$ \\
\hline Linguistic context & Husband and wife. \\
\hline Leia & $\begin{array}{l}\text { "Are we going to visit my mother this } \\
\text { weekend?" }\end{array}$ \\
\hline $\begin{array}{l}\text { Franklin } \\
\text { Leia }\end{array}$ & $\begin{array}{l}\text { "I don't think so, l've got a lot of things to do." } \\
\text { "You never want to visit my mother" Leia left } \\
\text { the room. }\end{array}$ \\
\hline
\end{tabular}

(Wired love, 2011)

In the dialogue it is seen how the conflict occurred between husband and wife, namely between Franklin and Leia. At first, the wife Leia took a Negative Face Threatening Act in the form of asking with a bald on record strategy or directly without redress, namely trying to invite her husband to visit his mother's house. Then the husband refused the request. This refusal is included as a Positive Face Threatening Act conveyed by using baldly on record with negative politeness redress. It can be seen from his utterance which said "I don't think so, I've got a lot of things to do." 
This statement was then responded by Leia saying "You never want to visit my mother" which is classified as complaining (Positive Face Threatening Acts) conveyed using a direct strategy without redress. The interesting thing in this case was that after the action was spoken by Leia, she then just left the room. This action can be classified as not doing the FTA (don't do the FTA). The reason why she did this action was not quite clear but I assumed that she did that because she was angry and she didn't want to listen to other reasons from her husband which could lead to further conflict. However, at the same time, what Leia did by leaving the room directly impact her face or she directly had given up her face (having a face loss or loss of self-esteem) in front of her husband.

Another Face Loss sample was done by Leia can be seen in this transcript:

(2) Physical context Epistemic context

Linguistic context

\section{Leia \\ Franklin \\ Leia}

Franklin

Leia

Leia
Inside the house.

: Franklin and Leia are a married couple. Leia tried to invite her husband to stay at home which then caused a conflict.

Participant's speech contains an FTA Social context: Husband and wife.

: "Will you stay at home tonight?"

"I'm already committed to visit Joe"

You never want to stay home. I very rarely ask you to do anything."

"I'm sorry, but I really have to go."

"Go ahead if you want to. l'll find somebody else to stay with me."

: Leia then left and cried.

(Wired love, 2011)

In this second dialogue, it can also be seen how the wife experiences a loss of self-esteem or face loss towards her husband. The beginning of the conflict occurred when Leia or the wife made a request or it can be classified as a Negative Face Threatening Act. She conveyed the action by using a bald on record strategy or directly without redress by saying "Will you stay at home tonight?" However, Franklin the husband made a rejection on the grounds that he already had an appointment with his friend Joe. It can be seen from his utterance "I'm already committed to visit Joe." This rejection is classified as a Positive Face Threatening Act with direct strategy without redress. The wife then took a Positive Face Threatening Act by expressing complaints by stating the utterance "You never want to stay home. I very rarely ask you to do anything."

Franklin, Leia husband, responded to her complaining by saying "I'm sorry, but I really have to go." This sentence is included in the Positive Face Threatening Act, or an action of refusal carried out with a direct strategy with redressive action (negative politeness). This utterance is classified as a redressive action (negative politeness) since in the statement the husband tried to apologize to his wife by saying "I'm sorry" before he did the refusal. The wife 
then counter attacked him by doing a Negative Face Threatening Act (using threat) by saying that she will try to find someone else who wants to live with her. At a glance, the use of this action was indeed seen that the wife tried to maintain her face or self-esteem, but unfortunately after she did the utterance Leia suddenly left the room and then she cried. The action of leaving the room and crying are classified into Don't do FTA meaning that the participant (Leia) is giving up his self-esteem lost or experiencing face loss even though previously she tried to maintain her face in front of his husband.

Based on the data it is clear that participants, namely husband and wife are fully involved in the conflict. In addition, this conflict is closely related to the usage of FTA. In a household conflict, it can be seen that the wife tends to give up more to her husband in order to maintain their household even if her face must be lost.

\subsection{Hearer (Wife) Intentionally Giving Up Her Face (Lose Face) to Avoid Conflict}

In general the wife often avoids further conflicts with her husband after the husband does the FTA. For example this can be seen in the following dialogues:

(3) Physical context : Inside the house

Epistemic

context

: $\quad$ Lary and Marry are a married couple. In one occasion, Marry had long waited her husband and prepared the dinner for him, but his husband Lary came late.

Linguistic context : Participant's speech contains an FTA

Social context : Husband and wife.

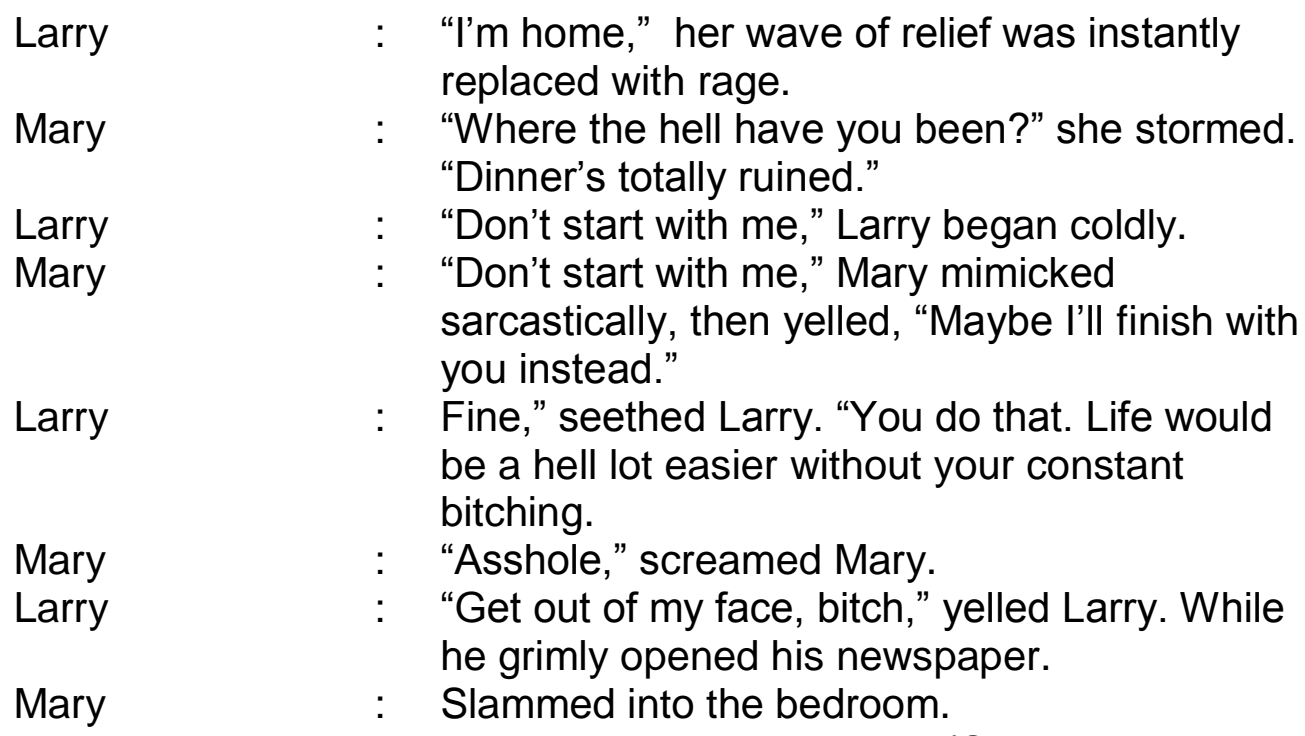

(Couple skills, 1994)

In this dialogue, Larry came and greeted his wife by saying "I'm home." However, Mary who had long waited her husband was angry with him and asked her husband by saying "Where the hell have you been?" she stormed. After that she said "Dinner's totally ruined." These utterance are classified as 
Positive Face Threatening Act since both of them contain complaining. Mary did this utterance on-record baldy without redress. Larry then answered his wife by using a threat "Don't start with me." This utterance is classified as Negative Face Threatening Acts and it was conveyed directly without redress. Mary then counter attacked her husband by mocking him and said "Don't start with me," which is classified as Positive FTA and she also tried to give him a threat by saying "Maybe l'll finish with you instead." Which is classified as a Negative Face Threatening Act. Both of these utterances was conveyed through on record strategy without redress.

Her husband Larry then got angry and said "Fine, you do that. Life would be a hell lot easier without your constant bitching." This utterance can be classified as a threat also so it means that Larry had chosen to do Negative Face Threatening Act directly without redress. Mary also got angry and said "Asshole." This utterance shows emotional action which can be classified as a Negative Face Threatening Act conveyed direct without redress. After that Larry yelled and requested his wife to leave by saying "Get out of my face, bitch." This requesting action can be classified as Negative Face Threatening Act conveyed directly or baldly on record without redressive action. Mary then just gave up her face by leaving the room and slammed the door. This action can be classified as not doing the FTA (don't do the FTA). What Mary did by leaving the room directly impact her face or she directly had given up her face (having face loss or loss of self-esteem) in front of her husband.

Another sample is as follow:

(4)

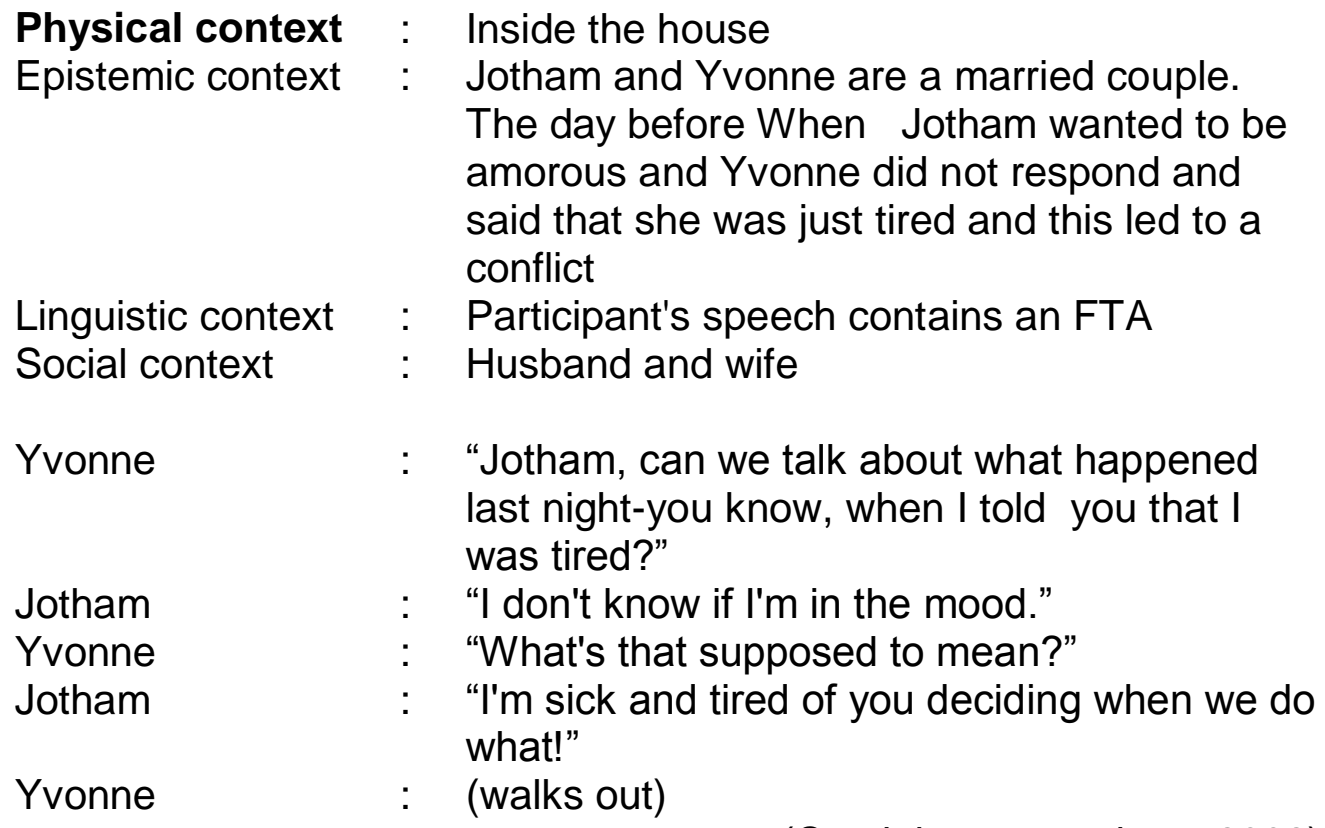

(Crucial conversations, 2002)

Yvonne tried to discuss the matter that happened last night, she then asked her husband to discuss it by saying "Jotham, can we talk about what happened last night-you know, when I told you that I was tired?" This request is classified as Negative Face Threatening Act with redressive action using positive politeness. It can be seen from the wife utterance saying her husband name "Jotham" before she requests her husband to do a discussion. The 
replied from her husband was "I don't know if I'm in the mood." This utterance can be classified as refusal which is a Positive Face Threatening Acts. In this utterance, Jotham does not say a refusal directly but it is embedded in the utterance which means that he uses an off-record strategy. This can be clearly seen after Jotham did the utterance Yvonne didn't understand clearly his husband utterance and said "What's that supposed to mean?"

Jotham then resented to his wife by saying "I'm sick and tired of you deciding when we do what!" this utterance can be said as emotional action which is classified as Negative Face Threatening Act directly without redress. The impact to hearer face in this situation or to Yvonne was that she walked out from the room. This action can be classified as don't do the FTA or she directly had given up her face (having face loss or loss of self-esteem) in front of her husband.

\section{Conclusion}

The impact of FTA on the hearer's face in household conflicts shows that hearer, in this case the wife, experienced more face loss even though the wife had tried to avoid face loss in front of her husband by maintaining her selfesteem but it seemed that women's emotional feelings dominate more. As Alan \& Barbara Pease (2002) said that naturally mostly men lie and women cry. This happens since both of genders are naturally born with different behaviors.

Based on the analysis, it can be seen that the hearer (wife) avoids conflict with her husband and gives up her face because of two things: 1) the hearer (wife) tends to avoid conflict because naturally they are lose from their feelings. Therefore, many of them chose not to counter attacking their husband and mostly they just walk out from the conflict or crying. 2) Hearer (wife) tends to avoid conflict in order to maintain the harmony of her family and tries to respect her husband.

After analyzed the impact of the face on the listener in relation to the use of Face Threatening Acts in household conflicts. We feels that there needs to be a more in-depth study in the non-verbal form to determine the degree of face loss. Therefore, we advise other researchers who are interested in discussing FTAs to examine this topic more deeply and comprehensively.

\section{References}

Beebe, L. M. (1995). Polite fictions: instrumental rudeness as pragmatic competence. In: Linguistics and the Education of Language Teachers: Ethnolinguistic, Psycholinguistics and Sociolinguistic Aspects. Georgetown University Round Table on Languages and Linguistics. Georgetown University Press, Georgetown (PP. 154-168).

Brown, P. \& Levinson, S.C. (1987). Politeness Some Universals in Language Usage.Cambridge: Cambridge University Press.

Culpeper, J. (1996). Towards an anatomy of impoliteness. Journal of Pragmatics 25, 349-367. 
Culpeper, J. (1998). (Im) politeness in drama. In: Culpeper, Jonathan, Short, Mick, Verdonk, Peter (Eds.), Studying Drama: From Text to Context. Routledge, London (PP. 83-95).

Georgakopoulou, A. (2001). "Arguing about the Future: On Indirect Disagreements in Conversation." Journal of Pragmatics 33: 1881-1900.

Djajasudarma. 1993. Metode Linguistik Ancangan Metode Penelitian. Bandung: Eresco

Goodwin, C., Goodwin, Marjorie, H. (1990). Interstitial argument. In: Grimshaw, Allen D. (Ed.), Conflict Talk: Sociolinguistic Investigations of Arguments and Conversations. Cambridge University Press, Cambridge (PP. 85117).

Haugh, M. (2010). "Jocular mockery, (dis)affiliation, and face." Journal of Pragmatics 42: 2106-2119.

Honda, A. (2012). Conflict Management in Japanese Public Affairs Talk Shows. Journal of Pragmatics 34: 573-608

Labov, W. (1972). Language in the Inner City: Studies in the Black English Vernacular. Blackwell, Oxford.

Labov, W., Fanshel, D. (1977). Therapeutic Discourse: Psychotherapy as Conversation. Academic Press, New York.

Laforest, M. (2002). "Scenes of Family Life: Complaining in Everyday Conversation." Journal of Pragmatics 34: 1595-1620.

Lee, J. S. (2008). The battle of the sexes in Korean entertainment media: Husband vs. Wife in TV drama. Journal of Pragmatics 40: 2175-2196.

McKay, M., Fanning, P., \& Paleg, K. (1994). Couple skills: Making your relationship work. Oakland, CA: New Harbinger Publications.

Mehan, H. (1990). Rules versus relationships in small claims disputes. In: Grimshaw, Allen D. (Ed.), 1578 J. Culpeper et al. / Journal of Pragmatics 35 (2003) 1545-1579 Conflict Talk: Sociolinguistic Investigations of Arguments and Conversations. Cambridge University Press, Cambridge (PP. 160-177).

Moleong, Lexy. 1993. Metodologi Penelitian Kualitatif. Bandung: PT Remaja Rosdakarya.

Nawawi, Hadari. 1991. Metode Penelitian Bidang Sosial. Yogyakarta: Gajah Mada University Press.

Patterson, K. (2002). Crucial conversations: Tools for talking when stakes are high. New York: McGraw-Hill.

Penman, R. (1990). Facework and politeness: multiple goals in courtroom discourse. Journal of Language and Social Psychology 9, 15-38.

Pease, A \& Barbara, P (2002). Why men lie and women cry. Orion Publishing Group. 
Rahman, F. (2019). Save the world versus man-made disaster: A cultural perspective. IOP Conference Series: Earth and Environmental Science, 110. doi:10.1088/1755-1315/235/1/012071

Tannen, D. (1990). Silence as conflict management in fiction and drama: Pinter's Betrayal and a short story "Great Wits". In: Grimshaw, Allen D. (Ed.), Conflict Talk: Sociolinguistic Investigations of Arguments and Conversations. Cambridge University Press, Cambridge (PP. 260-279).

Tatkin, S. (2011). Wired for love: How understanding your partner's brain and attachment style can help you defuse conflict and build a secure relationship. Oakland, CA: New Harbinger Publications.

Vuchinich, S. (1990). The sequential organization of closing in verbal family conflict. In: Grimshaw, A.D. (Ed.), Conflict Talk. Cambridge University Press, Cambridge, (PP. 118-138). 